\title{
Video-assisted ovariohysterectomy in domestic cats (Felis catus, Linnaeus, 1758) using two access portals ${ }^{1}$
}

\author{
Denise Cláudia Tavares ${ }^{\mathrm{I}}$, Fabiana Ferreira de Souza ${ }^{\mathrm{II}}$, Carolina Quarterone ${ }^{\mathrm{III}}$, Valeska Rodrigues ${ }^{\mathrm{IV}}$, Lucas de Freitas Pereira ${ }^{\mathrm{V}}$, \\ Maurício Veloso Brun" ${ }^{\mathrm{VI}}$, Gilson Hélio ToniollovII
}

DOI: http://dx.doi.org/10.1590/S0102-865020160020000002

${ }^{\mathrm{I}} \mathrm{PhD}$, Associate Professor, Department of Preventive Veterinary Medicine and Animal, Reproduction, School of Agrarian Sciences and Veterinary Medicine (FCAV), Universidade Estadual Paulista (UNESP), Jaboticabal-SP, Brazil. Conception, design, intellectual, and scientific content of the study; acquisition, analysis, and interpretation of data; critical revision.

"PhD, Full Professor, Animal Reproduction Division, Universidade de Franca (UNIFRAN), Franca-SP, Brazil. Conception, design, intellectual, and scientific content of the study; interpretation of data; critical revision.

IIIMaster, Associate Professor, Veterinary Anesthesia Division, Centro Universitário Cesumar (UNICESUMAR), Maringa-PR, Brazil. Acquisition of data, critical revision.

${ }^{\mathrm{IV}} \mathrm{PhD}$, Full Professor, Veterinary Ultrasound Division, UNIFRAN, Franca-SP, Brazil. Acquisition of data, critical revision.

vMSc, Associate Professor, Animal Science Division, and Fellow PhD degree, Postgraduate Program in Science, UNIFRAN, Franca-SP, Brazil. Acquisition of data, critical revision.

${ }^{V} \mathrm{PhD}$, Full Professor, Veterinary Surgery Division, Universidade Federal de Santa Maria (UFSM), Santa Maria-RS. Analysis and interpretation of data, critical revision.

VIIPhD, Full Professor, Department of Preventive Veterinary Medicine and Animal, Reproduction, School of Agrarian Sciences and Veterinary Medicine (FCAV), UNESP, Jaboticabal-SP, Brazil. Conception, design, intellectual and scientific content of the study; critical revision.

\begin{abstract}
PURPOSE: To describe video-assisted ovariohysterectomy (OHE) with two portals access in adult intact queens.

METHODS: Fifty-two females cats were used. A $4 \mathrm{~mm}$ cannula was positioned in the abdomen through an incision close to the umbilicus (first portal), and a pneumoperitoneum was established. A second portal was positioned in the midline of the pre-pubic region. Females were positioned in right lateral recumbency to locate the left ovarian pedicle, and the uterine horn was held by a transcutaneous suture. The pedicle was cauterized and incised. The procedure was then performed on the contralateral ovary. The ovaries were exteriorized from the abdomen, along with the uterus, through the second access point. The uterine body was exposed, fixed and sectioned, and the abdominal incisions were sutured.
\end{abstract}

RESULTS: Surgeries were performed in an average of $41.4 \pm 14.2$ minutes. The main complications included hypotension (7.7\%) and subcutaneous emphysema (7.7\%), and $13.5 \%$ of the surgeries were converted to laparotomy.

CONCLUSION: Ovariohysterectomy using a video-assisted technique and two access portals is safe, has minimal risks and is effective for the spaying of queens.

Key words: Castration. Video-Assisted Surgery. Hysterectomy. Ovary. Cats 


\section{Introduction}

Laparoscopic and video-assisted surgeries are not novel procedures, but they are procedures that need to be adjusted for veterinary medicine ${ }^{1}$. Laparoscopy is used in veterinary medicine due to advantages such as the diagnosis and treatment of multiple problems during the same surgical procedure. In medicine, the rapid return to normal activities and the decreased need for analgesics and anti-inflammatory medications in the postoperative period make video-surgical procedures more attractive than conventional surgery ${ }^{2}$.

Some disadvantages of laparoscopy are the cost of the equipment and the need for more than one surgeon to perform the surgery, as well as the learning curve associated with the technique ${ }^{3}$.

The surgical sterilization of dogs and cats is a common practice that increases their longevity and quality of life $e^{4,5}$ and contributes to controlling birth rates in these species ${ }^{4}$. It is considered a rational method that avoids mass euthanasia, a practice forbidden by most cities in the world ${ }^{6}$.

Although laparoscopic ovariohysterectomy (OHE) has numerous advantages for animal health, it is still not widely used in veterinary medicine ${ }^{2}$ but is gaining popularity ${ }^{6}$.

Cat breeding has become popular in many countries, because cats are able to live in relatively small areas and tolerate the absence of their owners, the vast majority of whom work outside the home ${ }^{7}$. This popularity has been reflected in the clinical-surgical routine. However, reports involving domestic cats remain scarce and have not matched their population growth, with little information available on the physiology and behavior of the species ${ }^{7}$.

Thus, our objective was to describe a video-assisted technique for OHE in domestic cats using only two portals of access and to describe the implications and complications of the procedure.

\section{Methods}

This study was conducted in accordance with the ethical guidelines recommended by the National Council for Control of Animal Experimentation and the College of Animal Experimentation, and it was approved by the Institution's Animal Care and Experimentation Ethics Committee under protocol number 005958-09.
Fifty-two adult (eight months to two years old) female cats weighing $2.0 \mathrm{~kg}$ to $4.0 \mathrm{~kg}$ were used. Before the surgeries, the queens underwent clinical and hematological examinations for inclusion in the study. Only healthy animals were used.

Food and water were withheld for eight and two hours, respectively, before surgery. $0.2 \mathrm{mg} / \mathrm{kg}$ midazolam (Generic drug, $5 \mathrm{mg} / \mathrm{mL}$, União Química, Farmacêutica Nacional S/A, EmbúGuaçu-SP, Brazil) and $2 \mathrm{mg} / \mathrm{kg}$ meperidine (Dolosal ${ }^{\circledR}$, cloridrato de petidina $50 \mathrm{mg} / \mathrm{mL}$, Cristália, Itapira-SP, Brazil) were administered together as intramuscular premedications. The cats were anesthetized intravenously with $4 \mathrm{mg} / \mathrm{kg}$ propofol (Propovan ${ }^{\mathbb{R}}$ $10 \mathrm{mg} / \mathrm{mL}$, Cristália, Itapira-SP, Brazil) and maintained under inhalation anesthesia with isoflurane (Isoforine, Cristália, ItapiraSP, Brazil) vaporized in $100 \%$ oxygen $(200 \mathrm{~mL} / \mathrm{kg})$ in a nonrebreathing system (Figure 1). The animals received prophylactic antibiotics (40.000 IU/kg benzathine penicillin G, Benzetacil ${ }^{\mathbb{R}}$ 1.200.000 UI, Eurofarma Laboratórios Ltda, Sao Paulo-SP, Brazil) intramuscularly before the surgery.

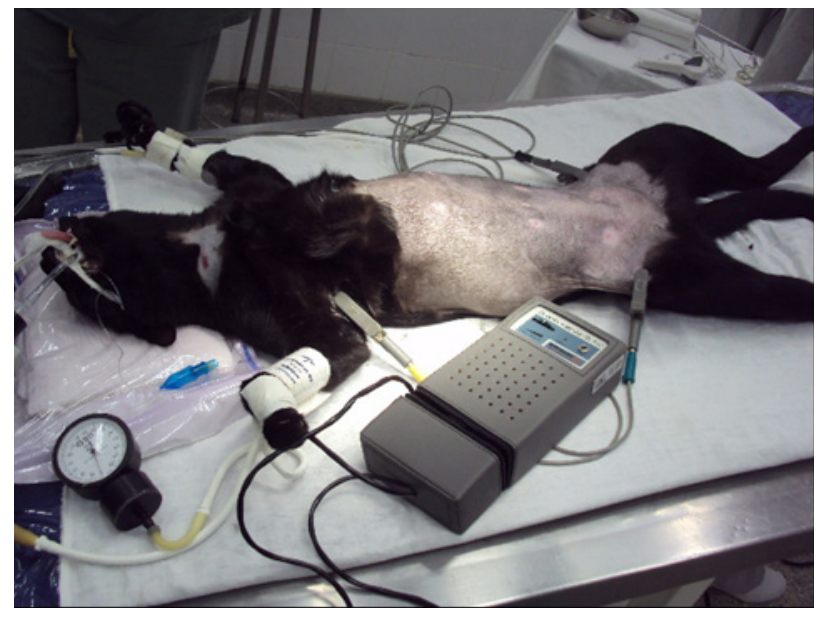

FIGURE 1 - Cat shaved for the laparoscopic OHE.

The equipment and instruments used in the videoassisted procedures included an electrical carbon dioxide $\left(\mathrm{CO}_{2}\right)$ insufflator (Model $\mathrm{CO}_{2}$ - OP - Pneu, Wisap, Germany), a xenon light source (Xenos light 175 Watt, Karl Storz, Storz, EUA), a fiber optic light cable (Xenon nova ${ }^{\circledR} 300$ - Karl Storz, Storz, EUA), a micro camera xenon light source (Veterinary video camera III, PAL/NTSC, Karl Storz, Storz, EUA), a 14' video monitor (PVN - 14N5U, Triniton, Sony), a 5-mm-diameter rigid endoscope 
$\left(0^{\circ}\right)\left(\right.$ HOPKINS $^{\circledR} \mathrm{O}^{\circ}$, Karl Storz, Storz, EUA), and a basic set of instruments (short threaded trocars $5 \mathrm{~mm}$ in diameter, a Babcock atraumatic grasper clamp, laparoscopic Metzenbaum scissors and bipolar cautery forceps).

All queens were shaved, followed by disinfection with a solution of $2 \%$ chlorhexidine gluconate. The patient was placed in dorsal recumbency, and an incision of $0.5 \mathrm{~cm}$ was made close to the umbilical scar. A $5 \mathrm{~mm}$ cannula was introduced into the abdomen (first access) and fixed by suture (2-0 nylon, loop triangular needle $1 / 2$ to $2 \mathrm{~cm}$, Poly Suture Indústria e Comércio Ltda, São Sebastião do Paraíso-MG, Brazil) to the skin using the rubber stopper of a $20 \mathrm{~mL}$ sterile syringe passed through the cannula (Figure 2). The abdominal cannula position was checked telescopically before beginning insufflation with $\mathrm{CO}_{2}$ to establish a pneumoperitoneum. The pneumoperitoneum was started by connecting the silicone hose inflator (previously adjusted to a slow flow and an automatic pressure of $4 \mathrm{mmHg}$ ) at the cannula, and was maintained at a maximum pressure of $8 \mathrm{mmHg}$.

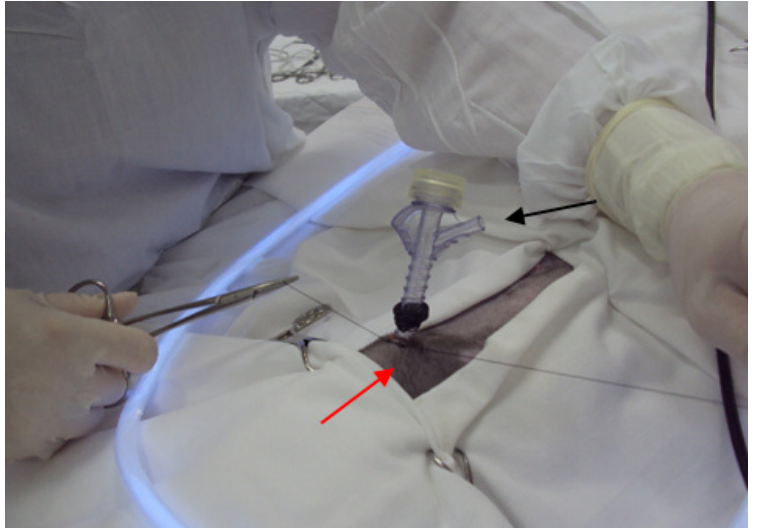

FIGURE 2 - Fixation of the first trocar (red arrow), Location of the $\mathrm{CO}_{2}$ hose for the insufflation of the abdominal cavity (black arrow).

A rigid $0^{\circ}$ endoscope, $5 \mathrm{~mm}$ in diameter, was introduced into the first access point. A xenon cold-light micro camera was coupled to the endoscope, enabling visualization and inspection of the abdominal cavity. A second access point was made under laparoscopic monitoring at the midline of the pre-pubic region (Figure 3).

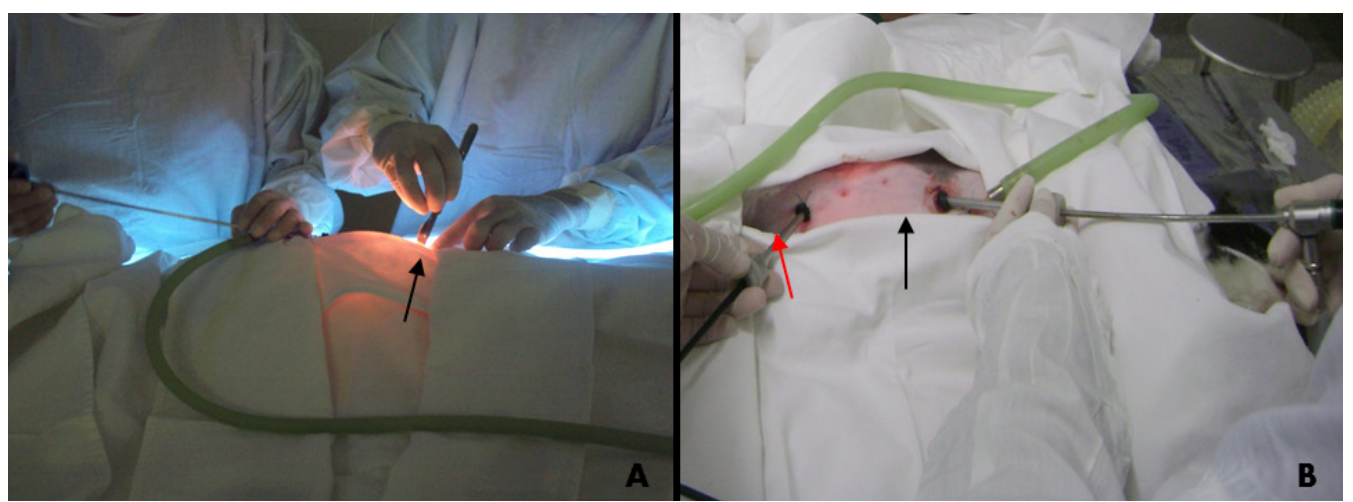

FIGURE 3 - Insertion of the second trocar, black arrow indicates the operator performing the section of the skin and muscle with a scalpel for insertion of the trocar (A). Positioning of the animal in right lateral recumbency; the red arrow indicates the first optical trocar; the black arrow indicates the second trocar with grasping forceps inserted through the diaphragm of the cannula (B).

The animals were rotated and placed in the right lateral recumbency to locate the left ovary. A Babcock atraumatic grasper was introduced through the second access point to clamp the ovarian suspensory ligament, which was mechanically ruptured.
Then, the uterus was suspended and fixed to the abdominal wall by an external transcutaneous suture with polyglactin $910 \mathrm{~N}^{\circ} 0(3 / 8$ triangular circular needle $3 \mathrm{~cm}$, Vicpoint ${ }^{\circledR}$, Point Suture do Brasil, Johnson \& Johnson, São José dos Campos-SP, Brazil) (Figure 4).

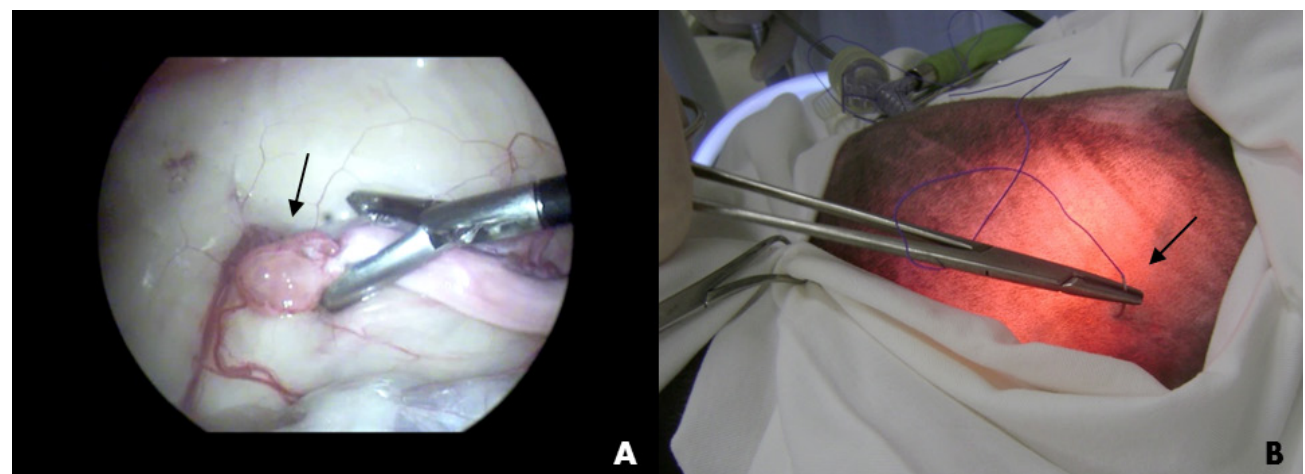

FIGURE 4 - Location and fixation of the left ovary (arrow) and uterine horn (A). Transparietal suture (arrow) (B). 
The Babcock grasper was replaced by a bipolar electrocautery introduced into the same access point. The mesovarium (ovarian pedicle) was cauterized at two equidistant points, from 5 to $10 \mathrm{~mm}$, for hemostasis of the ovarian vessels. Then, a section was made between the cauterized ovarian vessels followed by transection using Metzenbaum scissors through the second access point (Figure 5). The abdominal cavity was inspected for the presence of bleeding and the trocars were removed. The point of the transcutaneous fixation was released, and the same procedure was repeated on the contralateral ovary. After sectioning the pedicles, the cats were repositioned in dorsal recumbency, and the ovaries and uterus were fixed and gently pulled until they were completely externalized through the second access point (Figure 6).
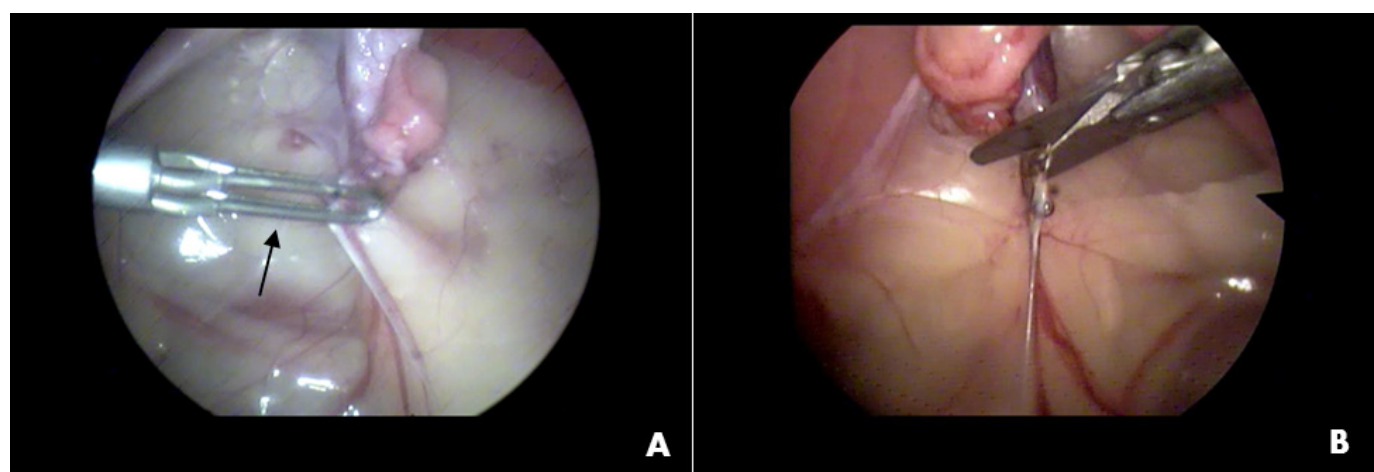

FIGURE 5 - Cauterization of the mesovary (pedicle) with bipolar forceps (arrow) (A). Incision of the mesovarium (pedicle) in the region between the points of cauterization $(\mathbf{B})$.

The uterine body was fixed immediately above the cervix (cranial region) with nylon (2-0 nylon, loop triangular needle 1/2 to $2 \mathrm{~cm}$, Poly Suture Indústria e Comércio Ltda, São Sebastião do Paraíso-MG, Brazil) at $1 / 2$ to $2 \mathrm{~cm}$ and then sectioned. The abdominal cavity was inspected again laparoscopically for the presence of bleeding, and then the micro camera was turned off and the abdominal cavity was deflated (Figure 6).

The two incisions were sutured with standard Sultan, and both the muscles and skin were sutured with simple interrupted stitches using nylon (2-0 nylon, loop triangular needle $1 / 2$ to $2 \mathrm{~cm}$, Poly Suture Indústria e Comércio Ltda, São Sebastião do Paraíso-MG, Brazil) thread with a $1 / 2$ or $2 \mathrm{~cm}$ circular or triangular needle, respectively. Immediately after surgery, the cats received $0.2 \mathrm{mg} / \mathrm{kg}$ meloxicam (Maxicam 0.2\%, Ouro Fino Saúde Animal Ltda., Cravinhos-SP, Brazil) intramuscularly and 3 $\mathrm{mg} / \mathrm{kg}$ tramadol hydrochloride (Generic drug, $50 \mathrm{mg} / \mathrm{mL}$, União Química Farmacêutica Nacional S/A, Embú-Guaçu-SP, Brazil) intravenously.

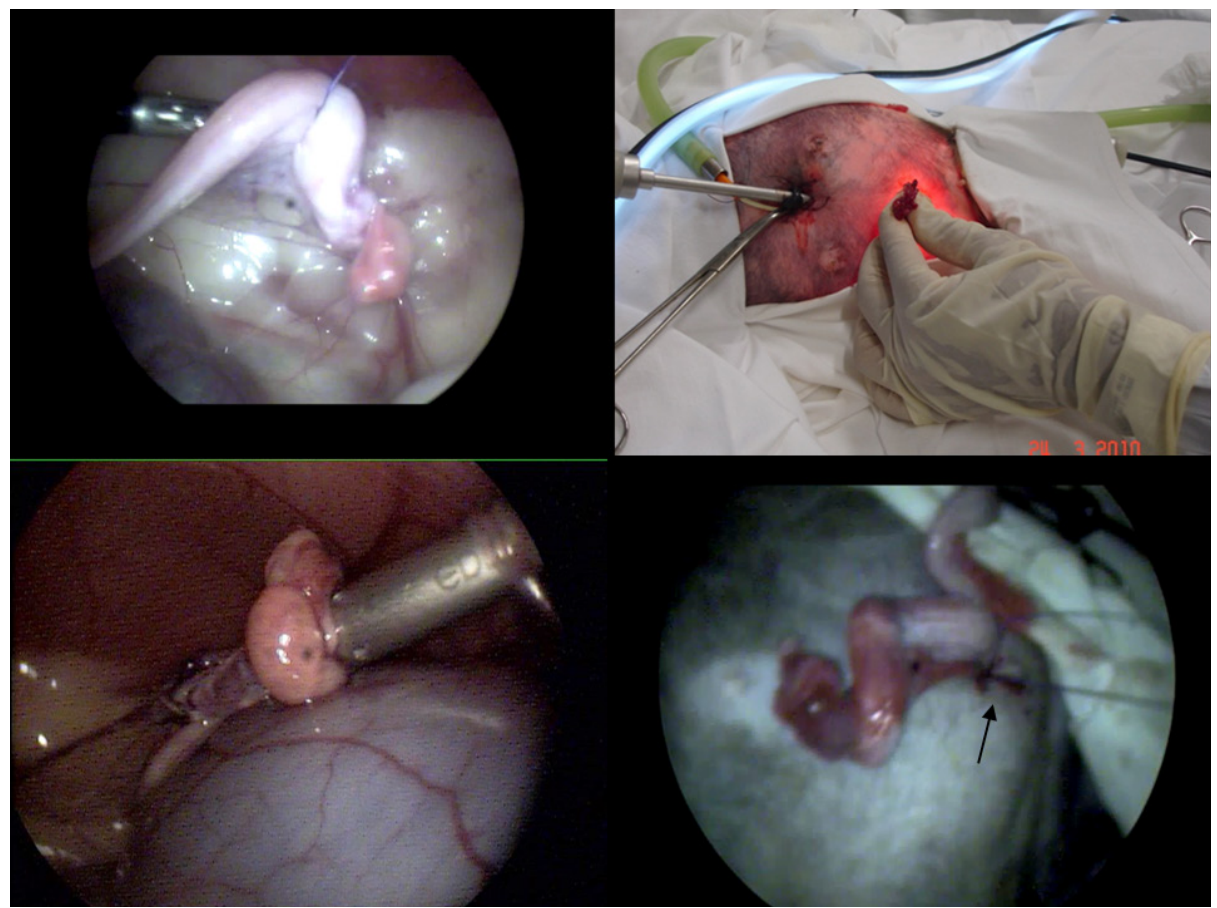

FIGURE 6 - Externalization of the block with the uterine horns, ovaries and uterine body (black arrow indicating the ovary) to ligature of the uterine body by conventional surgery for finalization of the OHE. 


\section{Results}

The mean and standard deviation of the total surgical time was $41.4 \pm 14.2$ minutes. All patients adequately recovered from anesthesia without incidents or complications. In this study, no assessment of pain was performed. Nevertheless, an observation of cats during the first eight hours after the procedure was performed, and the queens demonstrated characteristic recovery behaviors, including eating and drinking.

There were gas leaks through the incision in the first six animals $(11.5 \%)$ during the passage of the trocars, in which the pneumoperitoneum was maintained at a pressure of $8 \mathrm{mmHg}$.

Complications were observed during the first eight procedures, included a hemorrhage in the ovarian pedicle $(n=1$; $1.9 \%)$, hypotension $(\mathrm{n}=4 ; 7.7 \%)$, subcutaneous emphysema $(\mathrm{n}=4 ; 7.7 \%)$, wound dehiscence $(\mathrm{n}=1 ; 1.9 \%)$, a subcutaneous hematoma at the trocar insertion site $(\mathrm{n}=1 ; 1.9 \%)$ and conversion to laparotomy $(\mathrm{n}=7 ; 13.5 \%)$.

The cats that underwent video-assisted surgery in this study showed no significant changes in heart rate (HR) during the insufflation. Hypothermia (mean corporal temperature $=36.3 \pm$ $0.5^{\circ} \mathrm{C}$ ) and hypotension were observed in four queens.

\section{Discussion}

The use of minimally invasive surgery has progressively increased because of its positive results in some conventional procedures $^{8}$. Similar results were observed in this study, which identified few complications related to video-assisted surgery during ovariohysterectomies.

Subcutaneous emphysema and hemorrhage have been found in other studies in cats ${ }^{9}$, and all of our complications occurred in the first eight procedures. These complications are in agreement with other findings ${ }^{10}$, which also reported that the surgical time and number of complications decreased significantly after the first 10 procedures, after which they plateaued.

The surgical time in our study was greater than that of traditional surgical techniques for spaying in queens, ovariohysterectomy ${ }^{4}$ or ovariectomy ${ }^{11}$, but the surgical risks were diminished by inspecting the abdominal cavity during the procedure, which is not possible during other minimally invasive techniques ${ }^{12}$.

We cannot affirm that the queens returned to normal behavior after surgery because of the laparoscopic method. However, studies show that pain scores are significantly lower after laparoscopic surgery in $\operatorname{dogs}^{4,13}$, and there are significantly lower serum cortisol concentrations postoperatively in laparoscopic surgery than open surgery ${ }^{14}$. Similar results were found during the first 6 hours postoperatively when comparing natural orifice transluminal endoscopic surgery (NOTES), laparoscopy and open surgery for oophorectomy in dogs. In this case, laparoscopy resulted in decreased cortisol concentrations compared to NOTES and open surgery ${ }^{15}$. In cats, laparoscopic ovariectomies resulted in lower pain scores, and no female had intense postoperative pain when compared to either a conventional ventral midline open approach or a right flank approach ${ }^{16}$. Nevertheless, another study found no difference in cumulative 4-hour pain scores when comparing single-incision laparoscopic port ovariectomies using LigaSure $^{\circledR}$ or extracorporeal suture with open ovariectomies ${ }^{11}$. We also noted normal activity of the queens approximately 4 to 6 hours after surgery, which is in accordance with Culp et al. ${ }^{5}$, who found no alteration in activity monitored by accelerometer preand post-video-assisted ovariectomy in small dogs, in contrast to the open surgery which showed decreased activity post-surgery.

The method of hemostasis can influence surgical time. Bipolar electrocoagulation reduces surgical time when compared to a Nd:YAG laser $^{17}$, metal clip application ${ }^{9,18}$ or monopolar electrocoagulation ${ }^{9,19}$. Moreover, there is a marked reduction in time depending on surgical experience ${ }^{3}$ and safe sectioning of the ovarian pedicle using bipolar electrocoagulation ${ }^{17,18}$. The choice of bipolar electrocoagulation was made due to ease and safety, which may have contributed to reduced surgical time and the absence of important complications in the present study.

One of the major complications reported in the literature is liver and splenic injuries that occur with the introduction of the first trocar or Veress needle ${ }^{3,20}$, but this can vary according to the laparoscopic technique used ${ }^{13}$. This complication was not observed, because we opted for an open technique performed by micro-incision and the insertion of the cannula under visualization of the intracavity tissues, preventing damage to the vital organs.

Due to the elasticity of the skin of cats, fraying of one of the micro-incisions at the site of the first trocar was observed after establishing the pneumoperitoneum. This became a surgical complication, because it was impossible to maintain the pneumoperitoneum. To correct the situation, we performed a purse-string suture around the trocar, and the automatic gas inflator was kept at a high flow with a maximum pressure of $8 \mathrm{mmHg}$. The absence of experience with laparoscopic surgery in cats resulted in gas leaks through the incision during the passage of the trocars, 
which prevented the maintenance of the pneumoperitoneum. Thus, we used a maximum pressure of $8 \mathrm{mmHg}$, which was similar to that used by Schiochet et al. ${ }^{9}$. This pressure was sufficient to perform the OHEs and to conduct the surgical procedure appropriately without resulting in unwanted effects.

The hemodynamic effects depend on the intra-abdominal pressure $^{21}$ and are accentuated when the pressure is above 15 $\mathrm{mmHg}$; these effects are minimized when the pressure does not exceed $12 \mathrm{mmHg}^{22}$. Furthermore, the pressure of $8 \mathrm{mmHg}$ promoted no significant cardiorespiratory changes in cats. A pressure of $15 \mathrm{mmHg}$ results in an increased mean arterial blood pressure, but no surgical advantage is observed when comparing working space at $15 \mathrm{~mm} \mathrm{Hg}$ versus $8 \mathrm{~mm} \mathrm{Hg}^{23}$, which was clearly shown in our study.

The conversion from laparoscopic surgery to a laparotomy was an important complication, but this conversion should not be considered a complication because it is attributable to the learning curve that is essential to ensure patient safety ${ }^{24}$. In the literature, the number of surgeries converted to laparotomies tended to decrease with practice ${ }^{24}$, which coincided with our results showing that the conversion occurred only in the first surgeries.

Changes such as bradyarrhythmias, which are due to peritoneal stretching and vagal stimulation, may occur after the initiation of the pneumoperitoneum ${ }^{23}$; if this occurs, the insufflation should be stopped immediately but may be restarted after the patient is stabilized. This event was not observed in any cat in this study.

According to $\mathrm{Melo}^{8}$, low intra-abdominal pressure and controlled hyperventilation can decrease respiratory acidosis during pneumoperitoneum, preserving lung function postoperatively. In this study, no respiratory complications were observed in either the perioperative or postoperative periods, demonstrating the importance of ventilatory control of patients. This absence of respiratory complications can be attributed to the experience of the veterinary anesthesiologists in the present study.

Subcutaneous emphysema occurs after the inadvertent introduction of $\mathrm{CO}_{2}$ beyond the abdominal cavity or a leak in the gas, and it is a common complication of laparoscopy that is cited in various others studies, including in human medicine ${ }^{8,10,20}$. This complication was observed in four cats in this study, but it did not result in clinical significance and resolved spontaneously without the use of drugs.

The cats that underwent video-assisted surgery in this study showed no significant changes in their HR during the insufflation, which is consistent with Cohen et al. ${ }^{25}$. This study reported a constant HR or a slight increase in this variable that may have been caused by a sympathetic compensatory response to the decreased venous return or a result of greater absorption of $\mathrm{CO}_{2}$.

The decrease in body temperature during laparoscopic surgery has been previously discussed and is related to the pneumoperitoneum ${ }^{23}$. This occurs either because of cooling by the gas due to its expansion as it leaves the cylinder ${ }^{25}$ or because of anesthesia ${ }^{26}$, which depresses the thermostatic mechanisms of the hypothalamus and metabolism ${ }^{25}$. In our study, we observed hypothermia in some queens, which could be associated with both conditions. The hypotension observed in some cats was associated with the use of a propofol bolus, which promotes vasodilation ${ }^{21}$. The hypotension was reversed with the use of plasma expanders (3.5\% gelatin colloid solution, $20 \mathrm{~mL} / \mathrm{kg}$ ) and the use of a mattress and heat exchanger to raise the body temperature.

Hematomas are considered a common postoperative finding in video-assisted surgeries and are observed at the trocar insertion sites; this occurrence may or not be associated with the dehiscence of the skin sutures ${ }^{27}$. These complications were also observed in this study in one queen, but they were resolved in several days without the need for the systemic administration of drugs.

Suture dehiscence occurred in one animal in this study, and this was associated with a lack of rest in the postoperative period. This complication was resolved with debridement of the wound and application of a new suture.

Costa Neto et al. ${ }^{28}$ described a laparoscopic technique in dogs using three trocars for the passage of the optical and laparoscopic instruments. For optimal viewing of the uterine body, the authors preconized the elevation and fixation of the uterus in the region between the horns to the caudal abdominal wall using a transfixing suture, and this procedure avoided a fourth trocar. According to the authors, the performance of this technique allowed optimal viewing of the viscera, minimizing the maneuvers required to manipulate the uterus perioperatively and thereby preventing accidents related to the stages of the chamber, hemostasis and excision. A similar technique was also described in bitches to treat pyometra, without increasing the complication rate $^{29}$. In this study, only two trocars were used because cats have a small abdomen, which justifies the reduction in the number of portals. The external transfixion of the uterine horns made the introduction of a third trocar unnecessary. Therefore, the 
application of only two trocars associated with the transfixion point facilitated the execution of the video-assisted technique that was previously demonstrated in bitches ${ }^{30}$.

\section{Conclusions}

The disadvantages of video-assisted surgery were the requirement of more than one surgeon and equipment costs. Although inexperienced initially, the technique was easy to perform, and to our knowledge this study was the first to report two portals to perform assisted-laparoscopic surgery in cats. The advantage of this technique is the use of few instruments in the abdominal cavity, which is very small in the cat. Furthermore, the assisted-laparoscopic surgical approach with two portals described in this study was adequate and safe during ovariohysterectomy, and it represents an additional option for this minimally invasive procedure in domestic cats.

\section{References}

1. Dent TL. Training and privileging for new procedures. Surg Clin North Am. 1996;76(3):615-21. PMID: 8669020.

2. Malm C, Savassi-Rocha PR, Gheller VA, Oliveira HP, Lamounier AR, Foltynek V. Ovário-histerectomia: estudo experimental comparativo entre as abordagens laparoscópica e aberta na espécie canina- III. estresse pela análise do cortisol plasmático. Arq Bras Med Vet Zootec. 2005;57(5):584-90. doi: 10.1590/S010209352005000500003.

3. Davidson EB, Moll HD, Payton ME. Comparison of laparoscopic ovariohysterectomy and ovariohysterectomy in dogs. Vet Surg. 2004;33(1):62-9. PMID: 14687188.

4. Howe LM. Surgical methods of contraception and sterilization. Theriogenology. 2006;66(3):500-9. PMID: 16716381.

5. Culp WTN, Mayhew PD, Brown DC. The effect of laparoscopic versus open ovariectomy on postsurgical activity in small dogs. Vet Surg. 2009;38:811-7. PMID: 19781023.

6. Carvalho MPP, Koivisto MB, Perri SH, Sampaio TSMC. Estudo retrospectivo da esterilização em cães e gatos no Município de Araçatuba/SP. Rev Cienc Ext. 2007;3:81-94.

7. Genaro G. Gato doméstico: comportamento \& clínica veterinária. MEDVEP, Rev Cienc Med Vet. 2005;3(9):16-22.

8. Melo MAC. Aprendizado do cirurgião e desenvolvimento tecnológico fazem a evolução da videocirurgia. Rev Bras Videocir. 2006;4:176-80.

9. Schiochet F, Beck CAC, Silva Filho APF, Contesini EA, Alievi $\mathrm{MM}$, Stedile R et al. Ovário-histerectomia laparoscópica em felinos hígidos: estudo comparativo de três métodos de hemostasia. Arq Bras Med Vet Zootec. 2009;61:369-77.

10. Solomon D, Bell RL, Duffy AJ, Roberts KE. Single-port cholecystectomy: small scar, short learning curve. Surg Endosc. 2010;24:2954-7. PMID: 20401494.

11. Coisman JG, Case B, Shih A, Harrison K, Isaza N, Ellison G. Comparison of surgical variables in cats undergoing single-incision laparoscopic ovariectomy using a ligasure or extracorporeal suture versus open ovariectomy. Vet Surg. 2014;43:38-44. PMID: 24279460 .

12. Kuan SY, Ticehurst K, Hoffmann KL, Crosby D, Barrs VR. Intestinal strangulation after elective ovariohysterectomy. J Feline Med Surg. 2010;12(4):325-9. PMID: 20227316.

13. Devitt CM, Cox RE, Hailey JJ. Duration, complications, stress, and pain of open ovariohysterectomy versus a simple method of laparoscopic-assisted ovariohysterectomy in dogs. J Am Vet Med Assoc. 2005;227(6):921-7. PMID: 16190590.

14. Marcovich R, Williams AL, Seifman BD, Wolf Jr JS. A canine model to assess the biochemical stress response to laparoscopic and open surgery. J Endourol. 2001;15(10):1005-8. PMID: 11789976.

15. Freeman LJ, Rahmani EY, Al-Haddad M, Sherman S, Chiorean MV, Selzer DJ, Snyder PW, Constable PD. Comparison of pain and postoperative stress in dogs undergoing natural orifice transluminal endoscopic surgery, laparoscopic, and open oophorectomy. Gastrointest Endosc. 2010;72(2):373-80. PMID: 20537637.

16. Gauthier O, Holopherne-Doran D, Gendarme T, Chebroux A, Thorin C, Tainturier D, Bencharif D. Assessment of postoperative pain in cats after ovariectomy by laparoscopy, median celiotomy, or flank laparotomy. Vet Surg. 2015;44(Supl 1):23-30. PMID: 24484303.

17. van Nimwegen SA, Kirpensteijn J. Laparoscopic ovariectomy in cats: comparison of laser and bipolar electrocoagulation. J Feline Med Surg. 2007;9(5):397-403. PMID: 17513153.

18. Mayhew PD, Brown DC. Comparison of three techniques for ovarian pedicle hemostasis during laparoscopic-assisted ovariohysterectomy. Vet Surg. 2007;36(6):541-7. PMID: 17686127.

19. van Goethem BEBJ, Rosenveldt KW, Kirpensteijn J. Monopolar versus bipolar electrocoagulation in canine laparoscopic ovariectomy: a nonrandomized, prospective, clinical trial. Vet Surg. 2003;32(5):464-70. PMID: 14569575.

20. Pope JFA, Knowles TG. Retrospective analysis of the learning curve associated with laparoscopic ovariectomy in dogs and associated perioperative complication rates. Vet Surg. 2014;43(6):668-77. PMID: 24962374.

21. Torres HO, Nunes CEL, Araújo Neto JP. Anestesia em cirurgia vídeo-laparoscópica. Rev Bras Anestesiol. 1995;1:21-32.

22. Leme MC, Natalini CC, Beck CAC, Brun MV, Contesini EA, Lima SDA, Stedile R. Pneumoperitônio com dióxido de carbono associado a três posições para laparoscopia em cães. Ciênc Rural. 2002;32:281-7.

23. Mayhew PD, Pascoe PJ, Kass PH, Shilo-Benjamini Y. Effects of pnemoperitoneum induced at various pressures on cardiorespiratory function and working space during laparoscopy in cats. Am J Vet Res. 2013;74(10):1340-6. PMID: 24066919.

24. Adikibi BT, Mackinlay GA, Munro FD, Clark C. Is conversion complication of laparoscopic surgery. J Laparoendosc Adv Surg Tech A. 2009;19(Supl 1):67-70. PMID: 18999976.

25. Cohen RV, Pinheiro Filho JC, Schiavon CA, Correa JLL. Alterações sistêmicas e metabólicas da cirurgia laparoscópica. Rev Bras Videocir. 2003;1:77-81.

26. Costa Neto JM, Uscátegui RAR, Carneiro RL, Nóbrega PI, Brito MA. Control de hipotermia con colchón térmico en perras durante ovario-histerectomía. Rev Med Vet (Bogota). 2011;22:11-9.

27. Beck CAC, Pippi NL, Brun MV, Contesini EA, Cunha AF da, Stedile R, Bonfada AT, Silva Filho APFG, Colomé LM. Toracoscopia nas hérnias diafragmáticas: estudo experimental em cães. Ciênc Rural. 2004;34(6):1857-67.

28. Costa Neto JM, Teixeira RGA, Baraúna ALI, Gordilho-Filho AO, Baraúna LCRI. Ovarisalpingohisterectomia laparoscópica em cadelas. VetNot. 2006;12:79-86. 
29. Collard F, Viguier E. A pyometra managed by laparoscopic ovariohysterectomy in a dog. Rev Elev Med Vet Pays Trop. 2008;159(12):624-27.

30. Ataide MW, Brun MV, Barcellos LJG, Bortoluzzi M, Feranti JPS; Santos FR, Tomazzoni F, Brambatti G, Zílio PP, Oro G, Sartori LW, Monteiro AR, Zanella R. Ovariosalpingohisterectomia videoassistida ou convencional em cadelas com o uso de ligase atlas ${ }^{\circledR}$. Ciênc Rural. 2010;40:1974-9.

\section{Correspondence:}

Fabiana Ferreira de Souza

Departamento de Reprodução Animal e Radiologia Veterinária, FMVZ

Universidade Estadual Paulista

Distrito de Rubião Junior, $\mathrm{s} / \mathrm{n}^{\circ}$

18.618-970 Botucatu - SP Brasil

Tel.: (55-14)3880-2237

fafesouza@fmvz.unesp.br

Received: Oct 16, 2015

Review: Dec 17, 2015

Accepted: Jan 19, 2016

Conflict of interest: none

Financial source: CAPES

${ }^{1}$ Research performed at Veterinary Hospital, Universidade de Franca (UNIFRAN), Franca-SP, Brazil. 